\title{
UNDERSTANDING SENTENCING UNDER THE YOUTH CRIMINAL JUSTICE ACT'
}

\author{
JULIAN V. ROBERTS* AND NiCHOLAS BALA**
}

The authors provide an analysis of the complicated sentencing regime found in Canada's Youth Criminal Justice Act (YCJA) and compare the new Act to the previous Young Offenders Act. In comparison to the provisions of the Criminal Code that govern adult sentencing, the YCJA makes no reference to deterrence, has more focus on rehabilitation, and calls for lesser penalties than for adults. The authors point out that proportionality is a key principle for both sentencing youths and adults, but the aggravating elements enumerated in the YCJA are not the same as those in the Criminal Code. They further note that situations in which youth custody may be used are limited and that judges are directed to treat custody as a last resort and consider all alternatives. The authors conclude that the YCJA facilitates a more uniform treatment of young offenders, though the courts will continue to exercise considerable discretion. While it is clear that the use of custodial sanctions will decrease even without more community resources, in some places the coming into force of the new Act was accompanied by increased community resources which will also affect sentencing practices. The article concludes with a survey of some of the first cases decided under the YCJA, which reveal that custodial sanctions were avoided and rehabilitative principles played a major role in sentencing decisions.
Les auteurs donnent une analyse complète du régime compliqué de la détermination de la peine tel qu'il existe dans la Loi sur le système de justice pénale pour les adolescents (Loi) ainsi que des comparaisons utiles avec l'ancienne Loi sur les jeunes contrevenants et le Code criminel. Par rapport aux dispositions du Code criminel régissant la détermination de la peine pour les adultes, la Loi ne fait aucune référence à la dissuasion, est davantage centrée sur la réhabilitation et demande des peines moins sévères que dans le cas des adultes. Les auteurs font remarquer que la proportionnalité est le principe clé de la détermination de la peine chez les adultes et les jeunes, mais les éléments aggravants mentionnés dans la Loi ne sont pas les mêmes que ceux qui figurent dans le Code criminel. Ils soulignent aussi que les situations pour lesquelles on pourrait avoir recours à l'incarcération sont limitées et que l'on demande aux juges de n'y avoir recours qu'après avoir considéré toutes les autres possibilités. Les auteurs en arrivent à la conclusion que la Loi facilite un traitement plus uniforme des jeunes contrevenants, même si les tribunaux continueront à exercer une grande discrétion. Alors qu'il est clair que le nombre d'incarcérations diminuera, même sans augmentation des ressources communautaires, à certaines endroits, l'application de la nouvelle Loi est allée de pair avec une hausse des ressources communautaires ce qui aura également une incidence sur les pratiques relatives aux peines. L'article se termine avec un sondage fait sur les premiers cas jugés en fonction de la Loi qui révèle que l'on a évité des peines d'incarcération et que les principes de réhabilitation ont joué un très grand rôle à ce moment-là.

\section{TABLE OF CONTENTS}

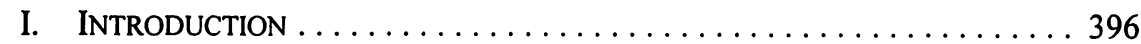

II. Preamble ................................. 398

III. DECLARATION OF PRINCIPLE: SECTION $3 \ldots \ldots \ldots \ldots \ldots \ldots \ldots$

IV. PURPOSE AND PRINCIPLES OF SENTENCING in Youth Justice COURT $\ldots \ldots \ldots \ldots \ldots \ldots \ldots \ldots \ldots \ldots \ldots \ldots$

- Department of Criminology, University of Ottawa.

- Faculty of Law, Queen's University.

1 The authors express their appreciation to the anonymous reviewers of this journal for helpful comments on a previous draft of the article. This article includes discussion of case law reported to June 15, 2003. 

A. The Purpose of Youth Justice COURT
SENTENCING: SECTION 38(1) .................. 402
B. ABSENCE OF REFERENCE TO DETERRENCE

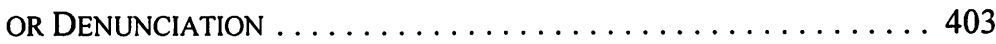
C. THE PRINCIPLES OF YOUTH
Justice Court SENTEnCING . . . . . . . . . . . . . . . . . 404

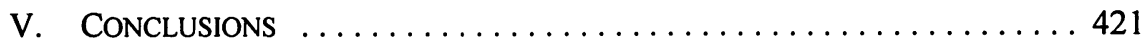

\section{INTRODUCTION}

On 1 April 2003, a new era in the treatment of adolescents in conflict with the law was inaugurated in Canada when the Youth Criminal Justice Act ${ }^{2}$ came into force. While the new Act retains the age jurisdiction of the Young Offenders $A c t^{3}$ as twelve years of age through to the eighteenth birthday, as well as the maximum youth sentence of the $Y O A$, being three years for most serious offences except murder (at ten years), the YCJA articulates new principles for the sentencing of young offenders and creates new sentencing options.

Although the new $A c t$ is complex, it has two primary objectives. For the relatively small number of youth found guilty of the most serious violent offences, the Act facilitates the process for imposing a more severe, adult sentence. ${ }^{4}$ For the vast majority of young offenders who commit less serious offences, however, the $Y C J A$ is intended to reduce Canada's reliance on the use of courts and youth custody. Under the $Y O A$, this country had one of the highest rates in the world of per capita use of courts and custody for adolescent offenders. ${ }^{5}$ Although there clearly remains an important role for custody of young offenders under the $Y C J A$, Canada made too much use of this expensive and often ineffective response to youthful offending under the $Y O A$.

The sentencing provisions contained in Part 4 of the $Y C J A$ represent a significant break with the past: they constitute the most systematic attempt in Canadian history to structure judicial discretion regarding the sentencing of juveniles. ${ }^{6}$ The sentencing provisions and

2
S.C. 2002 , c. 1 [YCJA, or $A c t]$.

R.S. 1985 , c. Y-1 [YOA].

This purpose is clear from government publications explaining the Act. For example, several stress that "the new legislation will give the youth justice court the power to impose adult sentences" (Government of Canada, "Canada's Youth Criminal Justice Act: A New Land, A New Approach" (Ottawa: Department of Justice Canada, 1999) at 8). Others note that the legislation will result in "expanding the offences for which a young offender would be liable to adult sentences" (Canada, Department of Justice, News Release, "Minister of Justice announces Youth Justice Strategy" (12 May 1998)).

There are significant methodological difficulties in accurately comparing rates of use of youth custody between countries, but at the time of unveiling the $Y C J A$ the federal government produced statistics to support the conclusion that Canada's use of courts and custody for adolescent offenders was higher than that of other industrialized countries. See Canada, Minister of Justice, A Strategy for the Renewal of Youth Justice (Ottawa: Department of Justice, 1998) at 20, and The Youth Criminal Justice Act: Summary and Background (Ottawa: Department of Justice, 2002) at 9 [Summary and Background]. These two documents set out the government's objectives in enacting the $Y C J A$. See also Jane B. Sprott \& Howard N. Snyder, "A Comparison of Youth Crime in Canada and the United States" (1999) 32 Criminol. 55.

For further detailed discussion of the Act, see Nicholas Bala, Youth Criminal Justice Law (Toronto: Irwin Law, 2003); Lee Tustin \& Robert E. Lutes, A Guide to the Youth Criminal Justice Act (Markham: Butterworths Canada, 2003). Additional commentary can be found in Forum: The Youth Criminal 
principles in the $Y C J A$ are quite different than both those that governed the sentencing of youths under the $Y O A$ and the sentencing regime applicable to adults ${ }^{7}$ that is contained in Part XXIII of the Criminal Code. ${ }^{8}$ In this article we review the principal components ${ }^{9}$ of the new sentencing regime for young offenders and draw some conclusions regarding the likely impact on sentencing in youth justice courts and the population of young persons in custody.

The YCJA contains detailed provisions that articulate the purpose and principles of sentencing young persons. The statute also prescribes specific criteria for the imposition of a term of custody in youth justice court. Taken together, these provisions constitute the most detailed sentencing guidelines short of numerical guideline systems, such as those found in some jurisdictions in the United States. The $Y C J A$ sentencing provisions therefore represent an ambitious attempt to change sentencing practices in the youth justice system and are more detailed and directive than juvenile justice reforms recently adopted in other common law jurisdictions. $^{10}$

While the $Y C J A$ does offer a more consistent and coherent set of principles for the sentencing of young offenders than the $Y O A$ did, the new $A c t$ is complex and the interpretation of its principles and provisions will doubtless constitute a challenge for youth justice court judges and appellate courts for years to come. For example, some principles are mentioned several times, in slightly different ways, and the relationship between certain important and sometimes inconsistent principles is not clearly explained. In R. v. D.C.L., one of the first reported decisions to apply the sentencing provisions of the $Y C J A$, Judge Gorman of the Newfoundland and Labrador Provincial Court complained: "The Act, like all legislation requires judicial interpretation. For some legislation this is an easy exercise. For others it is less so. This Act ... falls into the latter category as a result of some curious language. It almost appears that its drafters have been purposely obtuse."

Justice Act (2003) 40 Alta. L. Rev. Discussion of the Act in light of research on youth crime and justice can be found in Anthony N. Doob \& Carla Cesaroni, Responding to Youth Crime in Canada (Toronto: University of Toronto Press) [forthcoming]; Sanjeev S. Anand, "The Good, the Bad and the Unaltered: An Analysis of Bill C-68, the Youth Criminal Justice Act" (1999) 4 Can. Crim. L.R. 249.

7

Roberts, "Sentencing in Youth and Adult Court" (2004) Can. J. Crim. [forthcoming].

R.S.C. 1985, c. C-46 [Criminal Code]. Section 50 of the $Y C J A$, supra note 2 makes it clear that the principles and provisions of Part XXIII of the Criminal Code do not apply to youth justice courts, with a few noted exceptions, including the provisions governing victim impact statements (ss. 722, 722.1, and 722.2), pardons (ss. 748, 748.1, and 749), and the principle that special considerations apply when sentencing Aboriginal offenders (s. 718.2(e)).

9 In light of the number and complexity of provisions relating to sentencing, we do not discuss some issues, such as the use of pre-sentence reports and procedural issues in youth justice courts here; further discussion can be found in Bala, supra note 6, c. 8 .

For a review of international developments, see Michael Tonry \& Anthony Doob, eds., "Youth Crime and Youth Justice: Comparative and Cross-National Perspectives" in Crime and Justice, Vol. 31 (Chicago: University of Chicago Press, 2004) [forthcoming]; John A. Winterdyk, ed., Juvenile Justice Systems: International Perspectives, 2d ed., (Toronto: Canadian Scholars' Press, 2002). Similar conclusions are found in Nicholas Bala et al., eds., Juvenile Justice Systems: An International Comparison of Problems and Solutions (Toronto: Thompson Educational Publishing, 2002) [Juvenile Justice Systems]. 
This article is intended to provide judges, lawyers, and other readers with some assistance in understanding and interpreting the important yet complex sentencing principles found in the $Y C J A$, and to offer some explanation and context for the "curious language." The $Y C J A$ offers three increasingly explicit and directive levels of guidance for youth justice court judges in sentencing: a Preamble to the $A c t$; a Declaration of Principle [Declaration] that articulates general principles; and a statement of the purpose and principles for sentencing in youth justice court. We shall examine these three elements of the $A c t$ in turn, and consider how they may be applied in the context of some of the sentencing options specified in the Act.

\section{Preamble}

In recent years, it has become more common for Parliament to provide a preamble to criminal law legislation. ${ }^{12}$ The Preamble to the $Y C J A$ consists of general policy statements about youth offending and the youth justice system, and provides important insight into the direction taken with respect to sentencing. In light of the detailed sentencing principles contained in the Act itself, it is unlikely that the Preamble per se will play much of a role in determining sentencing outcomes. Rather, it is to be used by courts to help establish the general purpose of the legislation. However, since the Preamble sets the scene for the provisions that follow, it is worthy of some discussion. In addition to statements acknowledging the importance of community-based, multi-disciplinary approaches to the prevention of youth crime, and of responding to youth crime by addressing its "underlying causes," the Preamble sets out the central purpose of a youth justice system, and pronounces the need for a system that "ensures accountability" through the imposition of "meaningful consequences" for offending behaviour.

While "meaningful consequences" may be the result of a judicially-imposed sentence following a finding of guilt, a major theme of the $Y C J A$ is that "consequences" for adolescent offending should not always involve the use of courts. The $A c t$ is intended to reduce recourse to the use of youth justice court for less serious offences by encouraging more frequent precourt diversion of cases to various forms of "extrajudicial measures" by police and prosecutors. $^{13}$

The Preamble provides the first reference to the concepts of "rehabilitation and reintegration." The key sentencing principle of proportionality makes its appearance in the Preamble, although not in exactly the wording used for the sentencing of adults under the Criminal Code or in the sentencing provisions of the $Y C J A$ itself. Specifically, the Preamble declares that Canada should have a youth criminal justice system that "reserves its most serious intervention for the most serious crimes." ${ }^{.14}$ Finally, the Preamble identifies one specific problem that the sentencing provisions of the $Y C J A$ are intended to address, boldly stating that the youth justice system should reduce "the over-reliance on incarceration for 
non-violent young persons." ${ }^{15}$ This reference makes it clear that the Act is intended to promote the use of alternatives to custody and to discourage its excessive use as a form of sanction.

\section{DeClaRation OF PRINCIPLE: SECTION 3}

The YCJA Declaration ascribes specific goals to the youth criminal justice system and then identifies a number of features that must be emphasized by that system. With respect to the purpose of the statute, the $A c t$ declares that the "long-term protection of the public" is its over-arching aim. ${ }^{16}$ The temporal qualification "long term" may discourage courts from imposing punitive sanctions solely to protect society from the possibility of further offending in the immediate future. Custody has typically been used as a way of incapacitating the offender, at least in the short term. The phrase "long-term protection" - particularly when accompanied by specific strategies - suggests the use of remedies that change the young offender and his or her relations with the community, rather than those that simply isolate him or her from society for a period of time.

The goal of long-term public protection is to be achieved through the use of three strategies. The Declaration states that the youth criminal justice system is intended to

(I) prevent crime by addressing the circumstances underlying a young person's offending behaviour,

(ii) rehabilitate young persons who commit offences and reintegrate them into society, and

(iii) ensure that a young person is subject to meaningful consequences for his or her offence. ${ }^{17}$

The Declaration thus includes the primary purposes that might be ascribed to any juvenile justice system and notably fails to mention the more punitive utilitarian goals of deterrence and incapacitation. The absence of any direct reference to deterrence is one of the hallmarks of the YCJA and marks a major difference between the Act and s. 718 of the Criminal Code. The latter declares that one of the objectives in the sentencing of adult offenders is "to deter the offender and other persons from committing offences." ${ }^{18}$ While the $Y C J A$ makes no reference to "deterrence," and its omission ought to affect how sentences are imposed, the phrase "meaningful consequences" can be seen to embrace some elements of deterrence.

A society that permits criminal behaviour without imposing consequences on offenders invites lawlessness. The presence of meaningful consequences could therefore be interpreted as the existence of responses sufficiently rigorous to deter the offender and, possibly, other potential offenders. If not to serve as a deterrent, why should wrongful conduct be

is Ibid.; the Preamble introduces some of the terminology used throughout the $Y C J A$. Young offenders are now referred to as "young persons who commit offences." This break with the previous language of the YOA may represent an attempt to diminish the stigma associated with the phrase "offender" insofar as it may be seen to connote repetition and commitment to crime. For example, the word "burglar" brings to mind a different and more sinister image than the phrase "a person who has committed burglary." The new Act also replaces the term "disposition" that was used under the YOA, with the term "sentences," corresponding to the language employed at the adult level, and replaces the former "youth court" with "youth justice court."

16 Ibid., s. 3.

$17 \quad$ Ibid., s. 3(1)(a).

18 Criminal Code, supra note 8, s. 718(b). 
accompanied by "meaningful consequences"? In everyday discourse, when someone is informed that certain actions on their part will have "meaningful consequences," this information is imparted in an attempt to inhibit the conduct in question - deterrence, in other words. ${ }^{19}$ Although the term "deterrence" has disappeared from the statute, the concept of deterring young offenders may well continue to underlie the sentences that some judges impose.

What other interpretations might be placed on the phrase "meaningful consequences"? In one of the first judgments to interpret the $Y C J A$, Gorman J. suggested that this phrase "mandate[s] a very individualistic judicial approach to sentencing. The circumstances of the young person must be the primary focus and the sentence must be fashioned with the personal circumstances of the specific young person in mind."20 Such reasoning suggests that sentencing at the youth level should be more individualized than at the adult level and, consequently, there will be more variation in sentencing outcomes for specific offences in youth justice courts than in the adult courts. However, while it is true that youth justice courts should strive to ensure that consequences are meaningful to the particular youth, sentences should not be too individualized; s. 38(2)(b) emphasizes the need to impose sentences that are "similar to sentences imposed on young persons found guilty of the same offence in similar circumstances."21

The Declaration in the $Y C J A$ affirms the importance of having a youth justice system "separate from that of adults" that "emphasize[s]" certain desired characteristics, ${ }^{22}$ some of which are also found at the adult level, and some of which are clearly uniquely applicable at the youth justice level. The first characteristic is that the youth justice system should emphasize "rehabilitation and reintegration." 23 Second, the youth justice system should emphasize "fair and proportionate accountability that is consistent with the greater dependency of young persons and their reduced level of maturity." ${ }^{24}$ This characteristic thus conflates "accountability" and "proportionality," includes the central principle of juvenile justice that accountability is less important than for adults, and indicates that sentences for youth should be less severe than sentences for adult offenders.

It is difficult to know exactly what is meant by the term "proportionate accountability" and how it differs from the more conventional use of the term "proportionality" found later in the $A c t .{ }^{25}$ However, greater dependency and the reduced level of maturity of young persons are clear references to classic justifications for imposing mitigated punishments on juvenile

Deterrence is conceptually distinct from denunciation. Imposing sentences that have meaningful consequences for the offender clearly refers to the future conduct of that individual, and not to any social reaction, which is what denunciation is all about.

D.L.C., supra note 11 at para. 30.

YCJA, supra note 2.

Ibid., s. 3(1)(b).

Ibid., s. 3(1)(b)(i).

Ibid., s. 3(1)(b)(ii).

One possible interpretation of the phrase is that meaningful consequences which promote accountability become more meaningful, i.e., severe or intrusive, to reflect increases in the seriousness of the offence or the culpability of the young person. 
offenders; ${ }^{26}$ as such, they represent the first direction to judges that the severity of sentences in youth justice court should be less than that of sentences imposed in adult criminal courts. The same principle is reflected in the statutory limits on sentencing established by the $Y C J A$. The maxima prescribed by the $A c t$ are much lower than the statutory maxima at the adult level. For most offences, the maximum sentence that may be imposed in a youth justice court is two years, rising to three years for offences for which an adult is liable to a term of life imprisonment, and to ten years for murder.

As set out set out in s. 3(1)(c), the concept of proportionate accountability provides a limit on the four features of the measures that should be taken against young offenders. The use of the term "measures" indicates that these features apply equally to sanctions applied by the youth justice court after a finding of guilt and to the extra-judicial responses for youths diverted from the formal court process. Measures should "reinforce respect for societal values" as well as "encourage the repair of harm done to victims and the community."27 The latter requirement is the first of several references in the $A c t$ to restorative considerations. However, it is worth noting that the $Y C J A$ contains fewer restorative justice components than recent juvenile justice reforms in other common law jurisdictions, notably New Zealand and England and Wales. ${ }^{28}$ The measures taken must also be "meaningful for the individual young person given his or her needs and level of development" and, where appropriate, should encompass parties with a stake in the youth's rehabilitation, namely parents, extended family, and members of the community. ${ }^{29}$

The last consideration in s. 3(1)(c) is perhaps one of the most controversial, stating that the measures taken against young persons should "respect gender, ethnic, cultural and linguistic differences and respond to the needs of aboriginal young persons and of young persons with special requirements." ${ }^{30}$ This phrase requires consideration of gender, race, ethnic, and cultural background as well as Aboriginal status, both when deciding whether to divert a youth to extra-judicial measures and when a court is determining what type of sentence to impose. The wording is considerably broader than that of the Criminal Code provisions applicable to adults, which require that judges only pay special attention to the circumstances of Aboriginal offenders when imposing a sentence. ${ }^{31}$

See e.g. Andrew von Hirsch, "Proportionate Sentences for Juveniles: How Different Than for Adults?" (2001) 3 Punishment \& Society 221.

$Y C J A$, supra note 2 , ss. 3(1)(c)(i)-(ii).

Restorative justice at the level of juvenile justice has assumed particular importance in New Zealand, where the Children, Young Persons and Their Families Act 1989 (N.Z.), 1989/24 facilitates the resolution of youth crime problems outside the formal court structure (Gabrielle Maxwell \& Allison Morris, "Juvenile Crime and Justice in New Zealand" in Juvenile Justice Systems, supra note 10). In England and Wales, the Youth Justice and Criminal Evidence Act 1999 (U.K.), 1999, c. 23 introduces the possibility of referral to a youth offender panel which arranges reparative contracts between the young person and the victim (Loraine Gelsthorpe, "Recent Changes in Youth Justice Policy in England and Wales" in Ido Weijers \& Antony Duff, eds., Punishing Juveniles: Principle and Critique (Portland: Hart, 2002) [Punishing Juveniles]).

YCJA, supra note 2 , s. 3(1)(c)(iii).

Ibid., s. 3(1)(c)(iv).

Criminal Code, supra note 8, s. 718.2(e), "all available sanctions other than imprisonment that are reasonable in the circumstances should be considered for all offenders, with particular attention to the circumstances of aboriginal offenders." Section 50 of the $Y C J A$, supra note 2 provides that $\mathrm{s}$. 718.2(e) applies to the sentencing of young offenders, in addition to s. 3(1)(c)(iv) of the Act. See R. v. Borde 


\section{Purpose and Principles of Sentencing in Youth Justice Court}

One of the failings of the $Y O A$ was the very limited guidance it provided for youth court judges with respect to the determination of sentence. The federal government was definitely aware that the lack of a clear statement of sentencing principles in the $Y O A$ resulted in very wide disparities between the sentences that young persons in different provinces received for the same offence and in significant disparity between sentences imposed by different judges in the same community. ${ }^{32}$

The YCJA provides significantly greater and more consistent guidance for sentencing in youth justice court, beginning with a statement that articulates the purpose of sentencing young offenders. From the outset, it is important to note that s. 50(1) of the $Y C J A$ specifically excludes the adult sentencing provisions found in Part XXIII of the Criminal Code. Thus, judges are advised to conceptualize sentencing in youth justice courts in a distinctive way, although, as will be seen, there are important commonalities between the two regimes, most notably with respect to the principle of proportionality.

\section{A. The Purpose of Youth Justice Court Sentencing: Section 38(1)}

Before examining the Statement of Purpose found in s. 38(1), it is important to recall why such a provision is included in the Act. It is intended to offer general guidance to youth justice judges in the sentencing of young offenders. In jurisdictions that employ a sentencing matrix ${ }^{33}$ with a specific disposition (say, between six to nine months custody prescribed for a particular offence/offender combination), there is little need for a statement of purpose for sentencing. Judges simply follow the guideline sentence or decide to impose an exceptional sentence, known as a "departure." But in Canada, where sentencing is left to the discretion of the trial bench (guided by the appellate courts), it is necessary to give judges some clear indication of the purposes that sentencing is supposed to achieve. Otherwise, they will simply follow their own individual sentencing philosophies. The result will be wide disparities in sentencing comparable to those experienced under the $Y O A .^{34}$

To change sentencing practices, the statement of purpose should therefore be clear and should rule out certain sentencing philosophies. The statement of purpose for adults in $\mathrm{s} .718$ of the Criminal Code is not particularly helpful for judges grappling with the purpose of

(2003), 63 O.R. (3d) 417 (C.A.), where the Ontario Court of Appeal held that systemic racism and background factors affecting black Canadians might be taken into account in sentencing adults, especially where they can be shown to have played a part in the offence.

See Summary and Background, supra note 5 at 2.

Many American jurisdictions provide judges sentencing at the adult level with a two-dimensional sentencing grid in which one dimension is the seriousness level of the crime and the other is the number of previous convictions accumulated by the offender. In some states these grids apply also to juveniles. In Washington State, for example, judges sentence juveniles using a juvenile offender sentencing grid (see State of Washington Sentencing Guidelines Commission, Juvenile Disposition Manual 2002 (Olympia, Wash.: State of Washington Sentencing Guidelines Commission, 2002)).

The tendency among judges to pursue their own sentencing philosophies and the consequences for disparate sentencing has been demonstrated in a number of research studies. See T.S. Palys \& Stan Divorski, "Explaining Sentence Disparity" (1986) 28 Can. J. Crim. 347; John Hogarth, Sentencing as a Human Process (Toronto: University of Toronto Press, 1971). 
sentencing, as it simply lists all of the principal sentencing objectives. ${ }^{35}$ Similarly, the statement of purpose found in s. 38(1) of the $Y C J A$ offers no useful guidance to judges. Overall, however, the $Y C J A$ does provide much clearer sentencing direction than did the $Y O A$.

Consistent with the Declaration of Principles, s. 38(1) states that the overall purpose of young offender sentencing is to contribute to "the long-term protection of society." This goal is to be achieved by holding "a young person accountable for an offence through the imposition of just sanctions that have meaningful consequences for the young person and that promote his or her rehabilitation and reintegration into society." 36 The phrase "just sanctions" clearly implies proportional sentences and anticipates one of the criteria in s. 38(2), which deals specifically with sentencing principles.

As a practical guideline, however, it is difficult to see how the statement of purpose in s. 38(1) will help judges in youth justice court. To fulfill the purpose ascribed to sentencing under s. 38(1), a sanction in a youth justice court must

(i) contribute to long term protection of society,

(ii) hold a young person accountable,

(iii) consist of a just sanction,

(iv) carry meaningful consequences for the young person, and

(v) promote rehabilitation and reintegration into society. ${ }^{37}$

No sanction can accomplish all of these goals. What if some goals are fulfilled while others are not? What happens when the goals conflict? When a judge tries to determine whether a given sanction achieves the above aims, must she or he consider all of them seriatim? The same limitations that are associated with the statement of purpose pertaining to adults in s. 718 of the Criminal Code are present in s. 38(1) of the YCJA. The result is that judges, being practical people, are likely to pay little heed to this provision of the $A c t$, as it offers them no practical assistance in the difficult task of determining sentence. Fortunately, the principles of sentencing in youth justice court set out in s. 38(2) are more useful, as we shall shortly discuss. First, however, an important difference between the statutory sentencing purposes at the adult and youth justice court levels is worth noting.

\section{B. ABSENCE OF REFERENCE TO DeterRence OR DENUNCIATION}

While s. 38(1) offers little direct instruction as a statement of purpose to guide sentencing in youth justice court, it marks a significant departure from the sentencing purpose found at the adult level. Section 718 of the Criminal Code identifies the overall sentencing purpose as contributing to "respect for the law, and the maintenance of a just, peaceful and safe society." This goal is to be achieved by imposing "just sanctions" that fufill one or more of a list of sentencing objectives: denunciation, deterrence (special and general), incapacitation, 
rehabilitation, reparation (to victims and the community), and the promotion of a sense of responsibility in offenders and acknowledgment of harm to victims and the community. The only common elements in the statements of purpose applicable to young persons and to adults are rehabilitation and the expectation that courts will impose "just sanctions."

The absence of deterrence as an explicit purpose of sentencing at the youth justice court level marks a similar departure regarding the sentencing of young offenders. ${ }^{38}$ Deterrence was considered a legitimate sentencing objective under the $Y O A .{ }^{39}$ The omission of this utilitarian goal from the $Y C J A$ reflects the government's view that youth crime will not be reduced by a crime control strategy premised on the notion that more severe penalties will result in greater deterrence of youthful criminals. The reality is that youths who are prone to committing offences do not usually consider the consequences of their acts, let alone the severity of any sanction that a court might impose if they are apprehended. While some youths may be deterred from offending if there is an improvement in the enforcement of the law and an altered perception of the likelihood that they will be apprehended, there is no empirical support for the view that increasing the severity of sanctions imposed on youthful offenders will result in greater societal protection. ${ }^{40}$

\section{The Principles of Youth Justice Court Sentencing}

\section{ADULT-LEVEL SENTENCE AS A LIMIT ON SEVERITY OF YOUTH JUSTICE COURT SANCTION: SECTION 38(2)(a)}

To respond to the government's concern that dispositions imposed on youths under the $Y O A$ for certain common offences were sometimes harsher than sentences imposed on adults convicted of the same offences ${ }^{41}$ s. 38(2)(a) establishes the principle that the "sentence must not result in a punishment that is greater than the punishment that would be appropriate for an adult who has been convicted of the same offence committed in similar circumstances." ${ }^{\prime 42}$ However, there are two reasons why the principle articulated in s. 38(2)(a) seems likely to have only limited impact on youth justice court sentencing.

First, the evidence that judges under the $Y O A$ often imposed harsher sentences on young offenders who have similar records to adults is far from overwhelming. ${ }^{43}$ Several factors

A number of decisions under the $Y C J A$ have explicitly accepted that general deterrence is not to be a sentencing factor under the Act: see e.g. R. v. S.(B.R.), 2003 SKPC 84, Whelan J. [S.(B.R.)]; and R.v. M.(H.A.), [2003] M.J. 147 (Prov. Ct.), Swail J. [M.(H.A.)].

See e.g. R. v. J.J.M., [1993] 2 S.C.R. 421 [J.J.M.].

See discussion of research on this point in Bala, supra note 6 at 85. See also Anthony Doob \& Cheryl Webster, "Sentencing Severity and Crime: Accepting the Null Hypothesis" 30 Crime and Justice [forthcoming in 2003] who argue, after an exhaustive review of the literature, that even for adults, there is little evidence that sentence severity has any effect on the levels of crime in a society.

41 Canada, Department of Justice, YCJA Explained: Overview (Ottawa: Department of Justice Canada, 2002), online: Department of Justice <www.justice.gc.ca.en/ps/yj/repository/downloads/2010001.pdf> at 5 [YCJA Explained].

$42 Y C J A$, supra note 2.

43. While under the $Y O A$, young offenders received shorter terms of custody than adults, there were some situations in which youths may actually have received greater punishments than adults in similar circumstances. A study by Statistics Canada of sentencing for nine common offences found that incarceration rates were significantly higher for adult offenders, but that for those youth who did 
complicate attempts to compare sentencing patterns in youth and adult provincial courts, including the different forms of custody that may be imposed. However, aggregate sentencing statistics reveal that, in general, longer sentences are imposed on adult offenders. In 1999/2000, for example, the median sentence of imprisonment imposed in youth courts was 30 days. ${ }^{44}$ In contrast, the average prison sentence imposed in adult provincial courts in the same year was over three times as long, ${ }^{45}$ and even longer sentences were imposed on the most serious adult offenders in superior courts, where the average length of sentence in 20012002 was in excess of three years. ${ }^{46}$

The second reason to believe that s. 38(2)(a) will have limited practical effect concerns judicial awareness of sentencing patterns. In practice, it may be difficult for some youth justice court judges to accurately establish what an "adult level" sentence would be for the same "offence committed in similar circumstances." Although some judges involved in sentencing young offenders can rely on their experience in sentencing adults, youth justice court judges who do not regularly sentence adult offenders will have difficulty in establishing this benchmark. ${ }^{47}$

\section{Parity Within the RegiOn: SECTION 38(2)(b)}

Consistent with sentencing at the adult level, ${ }^{48}$ s. $38(2)$ (b) of the $Y C J A$ affirms the principle of parity in sentencing: "the sentence must be similar to the sentences imposed in the region on similar young persons found guilty of the same offence committed in similar circumstances. ${ }^{\circ 9}$

The difference between the adult and juvenile versions of this principle is marked by the inserted phrase "in the region." Although the $Y C J A$ does not expressly define the term, it may be operationalized by reference to the specific programs available to a given court, or it may

receive a custodial sentence, the lengths were sometimes longer than those for adults convicted of the same offence. This latter finding may reflect the fact that approximately half of the custodial sentences imposed in youth court involved open custody, as well as the fact that under the YOA some judges may have been using lengthy custodial sentences for relatively minor offences to achieve rehabilitative or social goals with some youths. See Trevor Sanders, "Sentencing of Young Offenders in Canada, 1998/99" (2000) 20:7 Juristat 1.

Mark Sudworth \& Paul deSouza, "Youth Court Statistics, 1999/00 Highlights" (2001) 21:3 Juristat at 9.

Brenda Bélanger, "Sentencing in Adult Criminal Courts, 1999/00" (2001) 21:10 Juristat at 7.

At present, superior court data are available from only a limited number of jurisdictions however, the exact average across four provinces and one territory was 1,187 days. Paul Robinson, "Adult Criminal Court Statistics, 2001/02" (2002) 23:2 Juristat at 10.

77 While there is variation across Canada as to which court is designated as the "youth justice court" under the $Y C J A$, in most jurisdictions the judges who deal with the vast majority of youth cases are the provincially-appointed judges who also deal with the majority of adult cases. The most serious charges against young persons will be dealt with by federally-appointed superior court judges who also deal with the most serious adult cases. In some jurisdictions, however, such as Quebec, the majority of youth justice court judges will not sentence adults on a regular basis.

Criminal Code, supra note 8, s. 718.2(b).

YCJA, supra note 2 , s. 38(2)(b). 
assume a wider definition in terms of the province or territory. ${ }^{50}$ Appellate courts will ultimately be left to resolve the ambiguity that surrounds this phrase. Questions of definition aside, there may be difficulties with its application. The term "region" could be narrowly defined. For example, it could refer to a relatively small area across which there is access to the same community-based services and custodial facilities. But if this is the case, how are sentencing patterns to be established? If judges within a region are split on sentencing practices, how are they to respond? Should the lenient judges increase the severity of their sentences or the severe judges become more lenient?

Further, one wonders why regional variation constitutes an appropriate factor for sentencing young persons, but not adults. What is the justification for this difference between adult and juvenile sentencing? ${ }^{51}$ It is hard to square this modified principle of parity with one of the principal goals of the legislation, namely, to reduce the degree of interprovincial disparities in youth sentencing. One of the most well-documented findings under the $Y O A$ was the wide variation in sentencing between different provinces, and one of the government's objectives in enacting the $Y C J A$ is to reduce disparities in sentencing patterns between provinces. ${ }^{52}$ While it is possible that s. 38(2)(b) may tend to reduce disparities in sentencing within provinces, the provision may come to be viewed as a codified justification for such variance. ${ }^{53}$ The insertion of "in the region" may well have the effect of entrenching the disparities in sentencing patterns that existed under the $Y O A$.

\section{PROPORTIONALITY AND Rehabilitation: SECTIONS 38(2)(c) AND 38(2)(e)(ii)}

The proportionality principle contained in s. 38(2)(c) - that is, that youth sentences "must be proportionate to the seriousness of the offence and the degree of responsibility for the offence" 54 - adopts almost exactly the same language as its adult counterpart, s. 718.1 of the Criminal Code. ${ }^{55}$ However, here, too, lies a subtle but potentially significant difference. The statement of purpose and principle for sentencing adults that was codified in 1996 in s. 718.1 has been criticized for a lack of clarity and for failing to provide adequate guidance by allowing judges to pursue a number of different sentencing purposes. ${ }^{56}$ Nevertheless, there is one way in which the statutory guidance for judges at the adult level is clear:

It is interesting to note that in one of the first sentencing decisions under the new regime for sentencing young persons, D.L.C., supra note 11 at paras. 35-36, Gorman J. queried, "What does the reference to the word region mean? Why did the drafters not use the word province?" and later concluded that region connotes "the province in which the sentence is imposed."

One explanation for this phrase is that it was inserted to placate and thereby defuse criticism of the $\mathrm{Act}$ from those provinces that wish to pursue their own youth justice strategy.

See Summary and Background, supra note 5 at 2, 8-9. For analysis of youth court sentencing patterns, see Jane B. Sprott \& Anthony N. Doob, "Understanding provincial variation in incarceration rates" (1998) 40 Can. J. Crim. 305. A survey of youth court judges also revealed wide variation in responses to youth crime; see Anthony N. Doob \& Lucien A. Beaulieu, "Variation in the exercise of judicial discretion with young offenders" (1992) 34 Can. J. Crim. 35. The provision may promote uniformity within a region while exacerbating variability across regions as different parts of the country or a given province develop their own sentencing tariffs.

YCJA, supra note 2 , s. 38(2)(c).

Criminal Code, supra note 8.

See Roberts \& von Hirsch, supra note 35. 
proportionality is identified in the marginal note to $\mathrm{s.718.1}$ as the "fundamental principle"57 of sentencing. As such, it is distinguished from the "other sentencing principles" found in s. 718.2 that, although important, are of lesser significance than is proportionality.

In contrast, proportionality is one of five principles set out in s. 38(2) of the $Y C J A$. While proportionality plays a key role in sentencing under the new $A c t$, it is less important than it is for adult sentencing. This is consistent with case law under the YOA that accepted that proportionality was to be given less weight in the sentencing of young offenders than in the sentencing of adults. ${ }^{58}$ If Parliament had intended proportionality to carry the same weight and play the same "fundamental" role in sentencing for youths and adults alike, it would have adopted the same words and structure as apply to adults under the Criminal Code.

One important example of a somewhat different approach to proportionality between adult and youth court is the much shorter maximum penalties that may be imposed on youths. Given the limited maximum duration of youth sentences under the $Y O A$, it was recognized that the adult sentencing principle that maximum sentences are to be reserved for the "most serious cases committed by the worst offenders" should be applied differently in cases that involve youths. ${ }^{59}$ This approach to proportionality is also applicable to the $Y C J A$. In one of the first sentencing decisions involving a very serious case - a break and enter that resulted in the shooting of a homeowner and some related offences - Lytwyn J. imposed the maximum three year sentence of custody and supervision (less time served in pre-trial detention), remarking that,

[u]nder the $Y C J A$, with its emphasis on proportionality, the principle that the maximum sentence should be reserved for the most serious offences committed by the worst offenders continues to require a different application. There is a narrower range than that available for adults and it would be unrealistic to reserve the maximum for the very worst possible case. ${ }^{60}$

The complex structure of those $Y C J A$ provisions that contain the purpose and principles of sentencing necessitates the consideration of a potential conflict between the rehabilitation of a young person and the need to impose a sentence that is proportionate to both the seriousness of the offence and the degree of responsibility that the young person bears for the offence. At the adult level, although rehabilitation is identified as one of the codified sentencing objectives in s. 718 (d) of the Criminal Code, the list of objectives in s. 718 is followed by what is referred to as the more general "fundamental principle" of adult sentencing, namely, proportionality.

Criminal Code, supra note 8, s. 718.1. Technically, marginal notes are not part of the statute and are only inserted for "convenience of reference only" (see Interpretation Act, R.S.C. 1985, c. I-21, s. 14). In practice, however, courts now consider these titles when interpreting and applying the provisions. See, for example, R. v. McIntosh, [1995] I S.C.R. 686 at 717, McLachlin J., dissenting for a discussion; and Sullivan, supra note 12 at 120. 
Which consideration takes precedence: rehabilitation or proportionality? The answer appears clear at the adult level: rehabilitation is but one of several secondary ${ }^{61}$ sentencing objectives, whereas proportionality is fundamental. Accordingly, the imposition of a disproportionately lenient sanction in order to promote the rehabilitation of an adult offender appears to be precluded by the Criminal Code.

At the juvenile level, however, the relationship between proportionality and rehabilitation is not quite so clear. The fact that the $Y C J A$ is permeated with references to rehabilitation, and that rehabilitation appears in both s. 38(1) - identifying the purpose of youth justice court sentencing - and s. 38(2)(e)(ii) - as one of the principles for the sentencing of young offenders - clearly indicates that rehabilitation is expected to have greater weight in youth justice court sentencing than is expected in adult courts. In addition, proportionality is not identified as "fundamental" in the YCJA in the way that it is in the Criminal Code. Together, these considerations suggest the likelihood that more tension between rehabilitation and proportionality will arise at the youth justice court level.

Can rehabilitative concerns totally trump proportionality in youth justice court? In Reference re Bill C-7,62 a Reference case brought by the Quebec government, the Quebec Court of Appeal ruled that provisions of the $Y C J A$ that place the onus on a youth found guilty of the most serious offences to justify the imposition of a youth sentence violate the Canadian Charter of Rights. The Court concluded that the other sentencing provisions of the $Y C J A$ are constitutionally valid, but observed that the United Nations Standard Minimum Rules for the Administration of Juvenile Justice ${ }^{63}$ provides that state reactions to juvenile crime should always be in proportion not only to the circumstances and gravity of the offence, but also to the needs of young people, and that the well-being of the young person must be a guiding factor in the sentencing of adolescents. Consequently, the Court of Appeal held that a youth justice court must strike a "balance" between these two principles in imposing a specific youth sentence under the $Y C J A .^{64}$ The Court of Appeal engaged in a limited analysis of the other provisions of the $Y C J A$ to bolster its conclusion, but relied most heavily on the text of the United Nations Convention on the Rights of the Child ${ }^{65}$ and the Beijing Rules. ${ }^{66}$ The Court concluded that "the proportionality of the sentence to the seriousness of the offence is not a preponderant principle, but one of the key principles of fundamental justice." 67

Criminal Code, supra note 8, s. 718 states that the "fundamental purpose of sentencing is to contribute ... to respect for law and the maintenance of a just, peaceful and safe society by imposing just sanctions that have one or more of the following objectives": denunciation; deterrence (special and general); incapacitation; rehabilitation; reparation (to victims and the community); and the promotion of a sense of responsibility in offenders and acknowledgment of harm to victims and the community. of that decision, see Sanjeev Anand \& Nicholas Bala, "The Quebec Court of Appeal Youth Justice Reference: Striking Down the Toughest Part of the New Act" (2003) 10 C.R. (6th) 397-418. GA Res. 40/33, 40 UN GAOR, Supp. No. 53, UN Doc. A/40/53 (1985) 207 [Beijing Rules]. Reference, supra note 62 at para. 147.

GA Res. 44/25, 44 UN GAOR, Supp. No. 49, UN Doc. A/44/49 (1989) 167. Supra note 63.

Reference, supra note 62 at para. 241. 
The federal government has announced that it will not appeal the conclusion in the Reference decision that some parts of the adult sentencing provisions of the $Y C J A$ are unconstitutional. The Quebec Court of Appeal's interpretations of the YCJA sentencing principles are technically obiter dicta, although they will very likely guide youth justice courts in that province. We would, however, argue that these statements are problematic and should not guide judges elsewhere, as, in our view, the $Y C J A$ clearly intends to make proportionality a preponderant sentencing principle.

Section 39(5) of the $Y C J A$ provides that a youth justice court cannot impose a custodial sentence as a substitute for "child protection, mental health or other social purposes." seems to preclude imposing a custodial sentence for rehabilitative purposes if doing so would represent a disproportionately intrusive response to the offence. Imposition of custody for rehabilitative purposes was not uncommon under the $Y O A$ and contributed to the high levels of the use of custody under that act. ${ }^{69}$ Further, while s. $38(1)(\mathrm{e})(\mathrm{ii})$ provides that the sentence is to be the one that is "most likely to rehabilitate the young person," the opening of s. $38(1)(\mathrm{e})$ states that this is "subject to" the proportionality principle of s. 38(1)(c). Thus, the only provision that explicitly links rehabilitation and proportionality creates a hierarchy wherein rehabilitation is "subject to" proportionality considerations.

What exactly does it mean, then, to say that rehabilitation plays a greater role - and proportionality a lesser role - in sentencing youths than it does in sentencing adults, while asserting that rehabilitative concerns are "subject to" the proportionality principle? Any youth justice court sentence must be a proportionate response to the offence and the circumstances of the offender. However, when there are reasonable prospects that a particular sentence would be most likely to rehabilitate the youth and adequate to hold the youth accountable, that rehabilitative sentence should be preferred over another, more severe sentence that is also within the range of proportionate alternatives. The $Y C J A$ clearly expects that judges will make greater efforts at the youth justice level than in adult court to construct sanctions that have a rehabilitative effect while still respecting the constraints of proportionality. Consideration of rehabilitative concerns and restraints on the use of custody may, for example, require greater consideration of such community-based sentencing options as the new sentence of deferred custody and supervision - a sentence that may both constrain a youth in the community and allow for the imposition of rehabilitative conditions. ${ }^{70}$

Ultimately, the decision about how to balance proportionality and rehabilitation must be made in the context of an individual offence and the circumstances of the youth, and will be constrained by the resources that are available in the community where the youth resides or

YCJA, supra note 2, s. 39(5).

See e.g. J.J.M., supra note 39.

The conditional sentence available to judges at the adult level offers a model by which to resolve apparently conflicting sentencing purposes. This sanction offers judges a way of encompassing both the punitive and restorative goals of sentencing and is, in many respects, similar to the $Y C J A$ sanction of deferred custody and supervision that can be imposed under s. 42(2)(p). See discussion in Sanjeev Anand, "Crafting Youth Sentences: The Roles of Rehabilitation, Proportionality, Restraint, Restorative Justice, and Race under the Youth Criminal Justice Act" (2003) 40 Alta. L. Rev. 943 at 946-51; and Julian V. Roberts, "Unearthing the Sphinx: The Evolution of Conditional Sentencing" (2001) 80 Can. Bar Rev. 1019. 
that are accessible through the youth correctional system. As noted in s. 39(3), important factors in assessing the likelihood of a youth being rehabilitated by any youth justice court sentence are the attitude of the youth and the availability of appropriate programs or resources. A pre-sentence report and the submissions of counsel should address these issues.

\section{RESTRAINT WITH RESPECT TO THE USE OF IMPRISONMENT: SECTIONS 38(2)(d) AND (2)(e)}

The principle of restraint regarding custodial sentences of imprisonment has long been part of the sentencing process in Canada. Two of the sentencing provisions in the $Y C J A$ advance that principle: ss. 38(2)(d) and (e).

Section 38(2)(d) adopts virtually the exact language found in s. 718.2(e) of the Criminal Code: "All available sanctions other than custody that are reasonable in the circumstances should be considered for all young persons, with particular attention to the circumstances of aboriginal young persons." "11 Further, and quite redundantly, s. 50 of the $Y C J A$ specifies that, from among the various Criminal Code sentencing principles, only s. 718.2(e) is expressly adopted for youth justice court sentencing.

The references to Aboriginal youth in ss.3(1)(c)(iv) and 38(2)(d) of the $Y C J A$ reflect the government's intention to attempt to lower the number of Aboriginal youth in custody. The over-representation of Aboriginal youth in the youth correctional system is as serious a concern as the over-representation of Aboriginal Canadians in the adult prison population. In 2000-2001, Aboriginal Canadians, who represent approximately three percent of the general population, accounted for 17 percent of provincial admissions to custody. ${ }^{72}$ Aboriginal youth account for approximately five percent of the juvenile population, while under the YOA they accounted for fully one-quarter of sentenced custodial admissions. ${ }^{73}$

Early versions of the $Y C J A$ that were introduced in Parliament did not include specific references to Aboriginal youth. ${ }^{74}$ References were added during the course of the Parliamentary review at the urging of witnesses appearing before the Committee studying the Bill. Despite a ringing endorsement from the Supreme Court in R.v. Gladue ${ }^{75}$ about the importance of giving special consideration to Aboriginal offenders at the adult level, this provision continues to attract controversy, with critics questioning why Aboriginal status per $s e$ - rather than having a disadvantaged background - should affect sentencing. ${ }^{76}$

YCJA, supra note 2, s. 38(2)(d).

Julian V. Roberts \& Ron Melchers, "The Incarceration of Aboriginal Offenders: Trends from 19782001" (2003) 45 Can. J. Crim. \& Crim. Just. 211.

Julie Marinelli, "Youth Custody and Community Services in Canada, 2000/01" (2001) 22:8 Juristat at 5.

Bill C-68, An Act in respect of criminal justice for young persons and to amend and repeal other Acts, 1st Sess., 36th Parl., (1999) (1st reading, 11 March 1999).

[1999] 1 S.C.R. 688, 171 D.L.R. (4th) 385, 23 C.R. (5th) 197.

A private member's bill that received first reading on 20 March 2003 calls for the repeal of the Aboriginal reference at both the adult and youth justice court levels (Bill C-416, An Act to amend the Criminal Code and the Youth Criminal Justice Act (Sentencing Principles), 2nd Sess., 37th Parl., (2003)). For discussion, see Philip Stenning \& Julian V. Roberts, "Empty Promises: Parliament, the Supreme Court and the Sentencing Aboriginal Offenders" (2001) 64 Sask. L. Rev. 137, and subsequent 
Regardless of the controversy over codifying special sentencing considerations for one particular ethnic group, it would clearly have been inconsistent for Parliament to direct judges to consider this factor for adults, but not to consider it at the youth justice court level. In its submission on the $Y C J A$, the National Criminal Justice Section of the Canadian Bar Association recommended that the $A c t$ include this provision. ${ }^{77}$

Sanjeev Anand predicts that "many Aboriginal young people will be sentenced more leniently than non-Aboriginal young offenders who have committed similar offences in similar circumstances." ${ }^{78}$ Some of the first reported cases under the Act that dealt with Aboriginal youth have cited s. 38(2)(d), as well as other provisions of the $A c t$, as justifications for imposing community-based sentences that provide greater prospects for rehabilitation..$^{79}$ While adult courts also discuss the importance of non-custodial sentences for Aboriginal offenders, s. 718.2(e) of the Criminal Code does not seem to have had much effect on reducing the over-representation of Aboriginal offenders in custody. Since 1996, the volume of non-Aboriginal adult admissions to custody has declined at a faster rate than that of Aboriginal admissions. ${ }^{80}$ This suggests that factors determining the number of Aboriginal offenders entering custody lie beyond the sentencing process. In light of this experience, it may be unrealistic to expect a rapid decline in the number of Aboriginal young persons sentenced to custody as a result of codification of this principle at the youth justice level.

The next principle, found in s. 38(2)(e), contains three components, one of which generalizes the principle of restraint. That is, "subject to" the principle of proportionality, a youth sentence must

(i) be the least restrictive sentence that is capable of achieving the purpose set out in subsection [38](1),

(ii) be the one that is most likely to rehabilitate the young person and reintegrate him or her into society, and

(iii) promote a sense of responsibility in the young person, and an acknowledgment of the harm done to victims and the community. ${ }^{81}$

This provision illustrates the complexities of sentencing young persons under the new statutory regime. Judges are simultaneously required to consider multiple, and possibly conflicting, aims. In addition, all three considerations are subject to the principle of proportionality contained in section $38(2)$ (c).

\section{Mitigating and Aggravating CiRcumstances: Section 38(3)}

At the adult level, Parliament has seen fit to codify five aggravating factors, but no mitigating circumstances. ${ }^{82}$ Some symmetry between the two categories of factors is

Colloquy in (2002) 65 Sask. L. Rev.

Canadian Bar Association, Stibmission on Bill C-3 (Ottawa: Canadian Bar Association, 2000) at 17.

See Anand, supra note 70 at 946.

See e.g. M.(H.A.), supra note 38; R. v. A. (E.S.), 2003 ABPC 86, Lipton J. [A.(E.S.)]; and R. v. M.(B.), 2003 SKPC 83, Turpel-Lafond J. [M.(B.)].

80 See Roberts \& Melchers, supra note 72 [emphasis added].

$81 Y C J A$, supra note 2 , ss. 38(2)(e)(i)-(iii).

82 Criminal Code, supra note 8, ss. 718.2(a)(i)-(v). 
established under the $Y C J A$, which specifies both aggravating and mitigating circumstances. Specifically, youth justice court judges are directed in s. 38(3):

In determining a youth sentence, the youth justice court shall take into account:

(a) the degree of participation by the young person in the commission of the offence;

(b) the harm done to victims and whether it was intentional or reasonably foreseeable;

(c) any reparation made by the young person to the victim or the community;

(d) the time spent in detention by the young person as a result of the offence;

(e) the previous findings of guilt of the young person; and

(f) any other aggravating and mitigating circumstances related to the young person or the offence that are relevant to the purpose and principles set out in this section. ${ }^{83}$

It is perhaps surprising that the most important mitigating factor relevant to young offenders - age - is not specified in this list. After all, the degree of mitigation accorded young offenders is generally held to vary inversely with their age: young persons near the lower limit of criminal responsibility of twelve years of age should receive a far steeper "discount" from the adult tariff than a 17-year-old. This correlation between age and severity of punishment is the one feature common to all Western juvenile justice systems. ${ }^{84}$ One reason why the offender's age is not present in the list of mitigating factors in s. 38(3) may be that the drafters of the legislation might have felt that the somewhat oblique reference to this consideration in the Declaration of Principle was sufficient. After all, s. 3(1)(b)(ii) specifies that "fair and proportionate accountability" requires consideration of the "reduced level of maturity" of youths. ${ }^{85}$

It is also curious that some of the statutory aggravating factors at the adult level do not appear in the $Y C J A$. Another way of achieving greater consistency between sentencing at the adult and juvenile levels would have been to codify important, common sentencing factors. While certain factors identified in s. 718.2(a) of the Criminal Code for adult offenders (such as evidence that the offender abused his spouse or common-law partner or child) have little relevance at the youth justice court level, other factors that are not mentioned in the $Y C J A$ but are in s. 718.2 may be relevant to youths. For example, as provided for adults in s. 718.2(a)(i), crimes motivated by bias, prejudice, or hate are committed by young persons. Indeed, there is evidence that a disproportionate amount of hate-motivated crime is committed by young offenders. Similarly, s. 718.2(a)(iii) might be relevant: sexual assaults

YCJA, supra note 2, s. 38(3)(a)-(f).

Even opponents of a separate youth justice system cleave to the principle of moderating punishments according to the age of the offender. For example, in Barry Feld, "Juvenile and Criminal Justice Systems' Responses to Youth Violence" in Michael H. Tonry \& Mark Harrison Moore, eds., Youth Violence 24 Crime and Justice 189 at 246-47, Feld advocates an explicit youth discount at sentencing which would employ a sliding scale whereby a 14-year old might receive 25-33 percent of the adult penalty, a 16-year old 50-60 percent, and so forth.

YCJA, supra note 2, s. 3(1)(b)(ii) states, "[t]he criminal justice system for young persons must ... emphasize ... fair and proportionate accountability that is consistent with the greater dependency of young persons and their reduced level of maturity." 
are sometimes committed by young persons ${ }^{86}$ made responsible for the temporary care of younger children. ${ }^{87}$

Restorative considerations in sentencing emerge in s. 38(3): a young person who has made reparation is clearly entitled to a mitigated sentence. However, the wording of s. 38(3)(c) seems quite restrictive in that its application is limited to "any reparation made." This suggests that gestures short of actual reparation - such as an expressed intention to make reparation, an acknowledgment of responsibility, or an expression of remorse - might be excluded. ${ }^{88}$ It seems likely, notwithstanding the narrow words, that the courts will adopt a generous interpretation of what constitutes a restorative gesture and will, for example, take account of genuine expressions of remorse as a mitigating factor ${ }^{89}$ If a broader definition is adopted, as is the case in other jurisdictions, young offenders will have greater incentives to undertake one or more of the restorative gestures that fall short of actually having to make monetary or material reparation.

Time in pre-trial detention will mitigate the severity of the sentence imposed. This places youth justice court sentencing in line with practices at the adult level. ${ }^{90}$ Although the Criminal Code does not specify a ratio of credit, most judges follow a "two for one" rule for adults who have served time in pre-trial detention. ${ }^{91}$ No guidance is given to judges with respect to the ratio of credit to be followed in youth justice courts, although it seems likely that a similar ratio will eventually emerge, given the fact that a youth will not receive "community supervision" time for the period spent in pre-trial detention and, in some places, may have lesser access to programming and services than youths in custody. ${ }^{92}$

Statistics Canada reports that juveniles accounted for 19 percent of sexual offences recorded by the police in 1997 Integration and Analysis Program, "Sex Offenders" (1999) 19:3 Juristat at 6.

Enhancing the severity of sentence to reflect the presence of these circumstances is not, of course, excluded by the $Y C J A$. Judges simply need to deem them relevant to the "purpose and principles" of youth justice court sentencing - because they reflect the "harm" done to victims, for example.

Kent Roach identifies another limitation with the $A c t$ 's formulation of this circumstance: the word "reparation" may be construed to have a strictly monetary or material connotation and might overlook other gestures that may be at once equally significant and more appropriate for younger individuals, many of whom will have no, or minimal, income (see Kent Roach, "The Role of Crime Victims Under the Youth Criminal Justice Act" (2003) 40 Alta. L. Rev. 965 at 983). See e.g. M. (H.A.), supra note 38.

*) Section 719(3) of the Criminal Code, supra note 8 provides that "in determining the sentence to be imposed on a person convicted of an offence, a court may take into account any time spent in custody by the person as a result of the offence."

"1 See Allan Manson, The Law of Sentencing (Toronto: Irwin Law, 2001) at 110.

92 For a case under the YCJA taking a "two-for-one" credit, see $S$.(B.R.), supra note 38 , although in (C.L.) D., supra note 60 , the judge only gave nine months' credit on a three year sentence of custody and supervision for six months in pre-trial detention. The justification for withholding credit for pre-trial detention under the $Y O A$ was that, unlike adult prisoners, young offenders in custody received no statutory sentence remission (Bala, supra note 6 at 413). However, there are other grounds for according such credit, one of which is that the physical and psychological privations of pre-trial detention can often be more aversive. 


\section{CRITERIA FOR THE IMPOSITION OF A TERM OF CUSTODY: SECTION 39}

In light of the $A c t$ 's Preamble and the stated position of the government about the need to reduce Canada's use of custody for young offenders, ${ }^{93}$ it is understandable that the $Y C J A$ contains a number of specific provisions that are intended to restrict the number of young persons receiving custodial sentences.

First, there are clear directions in the Preamble, the Declaration (s. 3), and the sentencing principles (s. 38), for judges to consider community based sentencing alternatives prior to imposing a term of custody. Second, in s. 39(1), the $A c t$ stipulates that a young person can only receive a custodial sentence if one of four conditions has been satisfied. Third, even if one of the conditions in s. 39(1) has been satisfied, in ss. 39(2) to (9), the Act provides judges with a number of factors to be considered prior to sending a young person to custody. Fourth, the $A c t$ creates new, alternative sanctions which may be imposed in some cases that would previously have resulted in imprisonment. These sanctions include a new deferred custodial sentence that is presumptively to be served in the community.

These strategies create a clear contrast with the adult sentencing provisions, for they contain no such criteria that must be fulfilled prior to the imposition of a term of custody. The introduction of criteria for the committal to custody reflects a general consensus that of all sanctions, incarceration is particularly burdensome for young offenders. ${ }^{94}$ The language of section 39(1) is quite directive:

A youth justice court shall not commit a young person to custody under section 42 (youth sentences) unless

(a) the young person has committed a violent offence;

(b) the young person has failed to comply with non-custodial sentences;

(c) the young person has committed an indictable offence for which an adult would be liable to imprisonment for a term of more than two years and has a history that indicates a pattern of findings of guilt ...; or

(d) in exceptional cases where the young person has committed an indictable offence, the aggravating circumstances of the offence are such that the imposition of a non-custodial sentence would be inconsistent with the purpose and principles set out in section $38 .{ }^{95}$

Thus, unless the case satisfies one of the four enumerated conditions, a young person cannot be committed to custody. Section 39 is clearly intended to reduce the use of imprisonment for young persons convicted of less serious offences - especially those that do not involve violence, such as infractions related to property, drugs or the administration of justice.

\section{ADDITIONAL CONSIDERATIONS FOR THE COURT \\ CONTEMPLATING IMPOSITION OF CUSTODIAL ORDER}

After identifying the four conditions in s. 39(1), one of which must be satisfied before a term of custody can be imposed on a young person, s. 39 of the Act provides a number of other directions that judges must consider before ordering a custodial sentence. 


\section{RESTRAINT (REPRISED)}

Section 39(2) offers judges with an additional aide memoire with respect to the principle of restraint in imposing custodial sentences, providing that

a youth justice court shall not impose a custodial sentence ... unless the court has considered all alternatives to custody raised at the sentencing hearing that are reasonable in the circumstances, and determined that there is not a reasonable alternative, or combination of alternatives, that is in accordance with the purpose and principles set out in section $38 .^{96}$

Furthermore, according to s. 39(3) youth justice court judges are also directed to "consider submissions relating to"

(a) the available community-based alternatives to custody;

(b) the likelihood that the young person will comply with a [community-based] sentence, taking into account [the youth's history of] compliance with previous non-custodial [sanctions]; and

(c) the alternatives to custody that have been used ... in similar cases. ${ }^{97}$

Finally, before imposing a custodial sentence, the court is obliged to consider any sentencing proposal made by a young person or his or her counsel ${ }^{98}$ and, unless waived by the youth and prosecutor, ${ }^{99}$ a pre-sentence report, which is to include information about available community resources and the willingness of the youth to avail him or herself of those facilities. ${ }^{100}$

As well, another provision provides an excluded ground for the imposition of a term of custody. According to s. 39(5), a youth justice court "shall not use custody as a substitute for appropriate child protection, mental health or other social measures." 101 Under the $Y O A$, some judges committed youths to custody (and pre-trial detention ${ }^{102}$ ) for social welfare rather than penal purposes, for example, when faced with a juvenile prostitute charged with a minor offence, believing that this was the only way in which to effect a positive intervention in the youth's life. ${ }^{103}$

Ibid., s. 39(2).

Ibid., s. 39(3)(a)-(c).

Ibid., s. 42(1).

Ibid., s. 39(7).

Ibid., s. $40(2)(d)(v)$.

Ibid., s. 39(5). For some reason, the phrase "in the region" is not employed in this reference to similar cases as it is in s. 38(2)(b), although it is also appropriate to consider s. 38(2)(b) in this context.

A discussion of pre-adjudication detention is beyond the scope of this article, but it is worth noting that under the $Y O A$, supra note 3 , about 60 percent of admissions into youth custody facilities were for preadjudication or pre-sentencing "remand admissions" (Marinelli, supra note 73 at 6). Section 29 of the YCJA, supra note 2 is directed at concerns about over-use of pre-trial detention, creating a presumption against detention on the basis that it is unlikely that the youth will commit an offence or interfere with the administration of justice (the secondary consideration in s. 515(10)(b) of the Criminal Code, supra note 8 ) once a youth is charged with an offence that could not result in a custodial sentence.

A survey of judicial officers found that a substantial proportion of young offenders were detained in custody for child welfare purposes (Anthony Doob, Youth Court Judges' Views of the Youth Justice System: The Results of a Survey (Research Report, Centre of Criminology, University of Toronto, 2001) [unpublished]). 
One way that young offenders (or, indeed, adult offenders) can be committed to custody is through application of the principle of "penal escalation," also known as the "step principle" of sentencing. Re-offending following the imposition of a non-custodial sentence such as probation can be seen by some judges as justification for the imposition of a term of custody, even though the fresh offence may be no more serious than the previous offence. Some judges concerned with preventing future offending may consider it to be a logical sentencing strategy to escalate the severity of sentences as an offender's convictions accumulate. This judicial logic is in no way prohibited by the $Y C J A$, though it is discouraged by s. 39(4), which states that "the previous imposition of a particular non-custodial sentence on a young person does not preclude a youth justice court from imposing the same or any other non-custodial sentence for another offence." 104 Although the intent of this provision is to reduce the use of custodial sentences, it remains to be seen whether it will in fact result in any substantial changes in judicial sentencing practices for young offenders.

\section{JUSTIFYING CUSTODY AND THE NON-IMPOSITION OF ALTERNATIVES: SECTION 39(9)}

With respect to the use of custody, the final direction to judges at the youth justice court level is contained in s. 39(9). It obliges judges to justify the imposition of a custodial rather than non-custodial sanction:

If a youth justice court imposes a youth sentence that includes a custodial portion, the court shall state the reasons why it has determined that a non-custodial sentence is not adequate to achieve the purpose set out in subsection 38(1), including, if applicable, the reasons why the case is an exceptional case under paragraph $(1)(d) .^{105}$

Some. judges may resent this provision, particularly when read in conjunction with s. 48:

When a youth justice court imposes a youth sentence, it shall state its reasons for the sentence in the record of the case and shall, on request, give or cause to be given a copy of the sentence and the reasons for the sentence. ${ }^{106}$

Taken together, these sections effectively require a court imposing a term of custody to provide reasons why the custodial sentence was imposed, as well as providing reasons why a non-custodial sentence was not imposed!

\section{Sanctions Available: Section 42}

Section 42(2) lists the 18 sanctions available to judges in youth justice courts. ${ }^{107}$ Three new sentences have been created for all jurisdictions: a judicial reprimand, a custody and supervision order (CASO), and a deferred custody and community supervision order (DCSO). Jurisdictions may also implement three additional sentencing options, namely, an

YCJA, supra note 2, s. 39(4).

Ibid., s. 39(9).

Ibid., s. 48.

Ibid., s. 42(2)(a)-(r). In addition, the $A c t$ permits the imposition of an adult sentence under certain conditions, thereby expanding the sentencing options available to a youth justice court. 
intensive support and supervision order, an attendance order with respect to a non-residential program, and an intensive rehabilitation custody and supervision order. As a result of the $Y C J A$, youth justice court judges in Canada now have a wider range of sanctions than most other common law jurisdictions. The increase in the range of available sanctions will, in all likelihood, have two effects: it will help to reduce the number of committals to custody as judges have more options from which to choose, and, at the same time, it may increase the variability of outcome at the sentencing stage.

The judicial reprimand - being very similar to an absolute discharge except that the record of a reprimand is retained for only two months as compared to 12 months for an absolute discharge ${ }^{108}$ - is unlikely to be invoked as a sanction in many cases, and then only in the least serious ones that would not, in any event, have resulted in a custodial sentence. ${ }^{109}$ However, the other two new options, the CASO and the DCSO will change the way that custody is imposed and served.

\section{CUSTODY AND SUPERVISION ORDER: SECTION 42(2)(n)}

One of the acknowledged deficiencies of custodial arrangements under the YOA was the lack of community supervision or after-care following a term of custody. This is a particular concern since the period immediately following release from custody is a time when there is a high risk of re-offending. Under the $Y C J A$ all custodial sentences will involve a period in a custodial facility, either open or secure, ${ }^{110}$ followed by a period of community supervision. With respect to all but the most serious offences, for which there is judicial flexibility to set the two periods, ${ }^{111}$ s. 42(2)(n) specifies that the first two-thirds of the sentence is to be served in custody, while the last third of the order will be served in the community under supervision. There is also provision in the $Y C J A$ for a youth justice court judge to review a sentence to allow for the early release of a young offender from custody to supervision in the community, or to order the youth to remain in custody to serve the last portion of the sentence. ${ }^{12}$

Although the conditional release mechanisms applicable at the adult level are more complicated, this change in the nature of youth custody sentences is another example of the movement towards more consistency between the juvenile and adult sentencing regimes. The $Y C J A$ 's transformation from the custodial provisions of the $Y O A$ is an important step forward. In addition to providing greater congruence between adult and juvenile sentencing, it reflects the sound correctional principle that supervising prisoners in the community prior to the expiry of their sentence carries considerable benefits, with respect to both the reduction of

Ibid., s. 119(2)(c).

A "reprimand" is even less onerous than an absolute discharge, as the record is retained for a shorter period. It will most likely be used in cases in which a judge is signalling to the prosecutor that this is not the type of case that should be taken to youth justice court, but rather should have been dealt with by some type of extrajudicial measure (see $R . v$. D.(K.), 2003 NSSF 13, Lynch J. [D.(K.)]).

Section 85 of the $Y C J A$, supra note 2 allows for a province to have more than two levels of youth custody and to permit the decision about the level of custody to be determined by the provincial director, subject to a review board hearing. All jurisdictions have chosen to retain two levels of custody and allow youth justice court judges to determine the level of custody at the time of sentencing.

Ibid., s. 42(2)(o) and (r).

Ibid., ss. 94-98. 
recidivism and the promotion of the individual's rehabilitation and reintegration into society. ${ }^{113}$

Since there has been no change to the maximum penalties contained in the $Y O A$, this reformulated sentence of custody will also reduce the amount of time served by young offenders. A nine month custodial sentence under the $Y O A$ now becomes six months in custody and three months in the community under supervision. An indirect consequence of implementing the CASO, thus, should be a reduction in the amount of time that most young persons spend in custody and among the populations in youth custody facilities. ${ }^{114}$

One possible judicial reaction to the new provisions could be to extend the total duration of an order to ensure that the young person spends approximately the same amount of time in custody as she or he would have spent under the YOA. The drafters of the $Y C J A$ appear to have been apprehensive of this possibility because s. 39(8) provides that

[i]n determining the length of a youth sentence that includes a custodial portion, a youth justice court shall be guided by the purpose and principles set out in section 38 , and shall not take into consideration the fact that the supervision portion of the sentence may not be served in custody and that the sentence may be reviewed by the court under section $94 .^{115}$

Despite the explicit prohibition in s. 39(8), are youth justice court judges still likely to consider the "discounted" community portion of a custodial order and then prolong the duration of the order? At the adult level, when determining sentence length, judges also should not consider the offender's potential release on parole or statutory release. However, the volume of case law and controversy that has surrounded this question suggests that such consideration does sometimes take place. ${ }^{116}$

\section{DEFERRED CUSTODY AND SUPERVISION ORDER: SECTION 42(2)(p)}

According to s. 42(2)(p), a youth justice court may make a DCSO for a specified period not to exceed six months. Section 42(5) identifies the statutory criteria that must be fulfilled:

The court may make a deferred custody and supervision order under paragraph (2)(p) if

(a) the young person is found guilty of an offence that is not a serious violent offence; and

113 For example, a major British study found that recidivism rates were lower for offenders released on parole in comparison to those released without any form of community supervision: Tom Ellis \& Peter Marshall, "Does Parole Work? A Post-Release Comparison of Reconviction Rates for Paroled and NonParoled Prisoners" (2000) 33 Austl. Crim. \& N.Z.J. 300.

The average time in custody under the $Y O A$, supra note 3 was relatively brief. Half of all young offenders sent to custody were released in under 30 days (Marinelli, supra note 73 at 7). The YOA also allowed for early review by a youth court and release from custody on probation but this occurred relatively infrequently, especially for shorter sentences, since the review process was cumbersome. YCJA, supra note 2, s. 39(8) [emphasis added].

116. See Manson, supra note 91 at 115; and Mary E. Campbell, "Sentencing and Conditional Release" in Julian V. Roberts \& David P. Cole, eds., Making Sense of Sentencing (Toronto: University of Toronto Press, 1999) at 249-54. 
(b) it is consistent with the purpose and principles set out in section 38 and the restrictions on custody set out in section 39.117

Since the DCSO is only to be imposed if the s. 39 criteria for the imposition of custody have been satisfied, it must be considered as a form of custody, albeit one that is threatened rather than executed immediately. This sanction bears more than a passing resemblance to the conditional sentence of imprisonment available to judges when sentencing adult offenders. ${ }^{118}$ This view is confirmed by at least one early judgment in which a DCSO was imposed following discussion of the conditional sentence. Moreover, the Court described the DCSO as "the youth equivalent to a conditional sentence." 119

The young person placed on a DCSO has to comply with a number of standard conditions, such as keeping the peace, appearing before the youth justice court when so required, and reporting to the police or other authority as instructed. ${ }^{120}$ In addition, a youth justice court may impose a number of other conditions, such as ordering the young person to make reasonable efforts to obtain employment. ${ }^{121}$ As well, judges may impose any provisions that they consider appropriate, "including conditions for securing the young person's good conduct and for preventing the young person from repeating the offence or committing other offences." 122 This last basket clause replicates almost verbatim the text of the analogous section pertaining to the conditional sentence for adult offenders in the Criminal Code, and might, for example, include a requirement that a convicted youth engage in some form of treatment or therapy. ${ }^{123}$

\section{RELATIONSHIP BETWEEN DCSO AND CONDITIONAL SENTENCE OF IMPRISONMENT}

While a full treatment of the relationship between the DCSO and the Adult Conditional Sentence of Imprisonment (CSI) requires more discussion than is possible here, some comments are in order. Although there are clear parallels, the two sanctions are not totally interchangeable. Indeed, it is no accident that the sentence in the $Y C J A$ carries a completely different name. Moreover, in all the government publications dealing with the new legislation (and describing the DCSO), there is no mention of the CSI. One explanation for the government's failure to explicitly link the CSI and the DCSO is the widespread criticism that has arisen when the CSI sanction has been imposed on an adult for a serious personal injury offence. However, another consideration is also at work.

To an important degree, sanctions can only be understood by reference to the sentencing philosophy within which they are embedded. The same sanction may have different incarnations at the adult and juvenile levels. The increased importance of rehabilitation at the juvenile level should be reflected in the construction of sanctions such as the DCSO. In

$117 Y C J A$, supra note 2, s. 42(5)

118 See Roberts, supra note 70.

$119 \quad$ M.(H.A.), supra note 38 at para 43.

120) These statutory conditions are listed in the YCJA, supra note 2, s. 105(2).

121 Ibid., s. 105(3).

122 . Ibid., s. 105(3)(h).

12.3 Criminal Code, supra note 8, s. 742.3(2)(f). 
Proulx ${ }^{124}$ the Supreme Court made it clear that a CSI should be constructed to contain both punitive and restorative elements. A CSI that was purely punitive would fail to reflect the restorative element of the sentencing reform that gave rise to the conditional sentence. On the other hand, a purely restorative or rehabilitative CSI would fail to reflect the fact that this sanction is intended to be a form of imprisonment. Following this logic, a CSI should contain both punitive and restorative elements in approximately equal measure. However, the $Y C J A$ equivalent should probably place greater emphasis on conditions that promote rehabilitation, as opposed to those that assure punishment, to reflect the difference in emphasis of these two goals at the youth justice level. The consequence is that the profile of DCSOs should look more rehabilitative and less punitive than conditional sentences imposed on adults convicted of the same crimes.

\section{AMBIT AND MAXIMUM DURATION OF DCSO AND CSI}

There are differences between the CSI and the DCSO, some of which are more apparent than real. The maximum for the Criminal Code conditional sentence is two years less a day, while under the $Y C J A$, a DCSO may not exceed six months. This difference reflects the limited accountability of youths compared to adults.

An important theoretical difference between the two sanctions concerns the ambit of offences to which they may be applied. The adult CSI is, in theory, available for any offence, except those that carry a minimum term of custody. In contrast, s. 42(5) of the $Y C J A$ provides that a DCSO may not be imposed for a "serious violent offence." This restriction in the $Y C J A$ is intended to prevent the widespread public and professional criticism that has arisen when an adult court imposes a CSI for a serious personal injury offence. In practice, however, this may not be a major distinction, since a judge in youth justice court who is inclined to impose a DCSO has considerable flexibility in determining what is a "serious violent offence," 25 while the Supreme Court of Canada has indicated that a conditional sentence for an adult offender will rarely be appropriate in cases where an offence has resulted in serious injury. ${ }^{126}$

What contribution will the DCSO make to the YCJA's goal of reducing the number of young persons entering custody? Much will depend on whether youth justice courts avoid the problem of "widening of the net." Section 42(5)(b) makes it clear that a DCSO is subject to the criteria for the imposition of a term of custody and is therefore, technically, a form of custody. If, however, the DCSO is to reduce the use of custody, it should not serve as the last alternative sanction for the less serious cases that technically would satisfy one of the criteria in s. 39(1) for a custodial sentence but would not, in practice, have attracted custodial sentence under the $Y O A$. The only way that this provision will reduce the number of admissions to custody is if it is applied to cases which under the old YOA would have seen the youth in question sent into custody. 
At the adult level, the CSI has had a significant effect in terms of reducing the number of provincial admissions to custody since the sanction was introduced in $1996 .{ }^{127}$ It remains to be seen how youth justice court judges will apply this provision and whether it will truly be an alternative to custody or, rather, whether it becomes the most restrictive form of community sentencing option. Some of the early reported cases that have used the DCSO have been serious and reveal that at least some judges are placing youth who have committed violent offences on DCSO who, under the $Y O A$, would have been placed in custody, provided that the judge is satisfied that there is a good prognosis for rehabilitation under the DCSO. ${ }^{28}$.

\section{Conclusions}

The coming into force of the $Y C J A$ represents a significant step towards more principled sentencing for young offenders, and should result in significantly less use of custody for adolescent offenders.

The Act contains a complex, detailed, and interrelated set of statements of purposes and principles, as well as specific sentencing provisions. Many elements of the $Y C J A$ echo sentencing provisions at the adult level, particularly with respect to the critical principle of proportionality. Nevertheless, important differences remain. What impact will the Act have on the sentencing of young persons and, more specifically, on the use of custody in youth justice courts? The clearer guidance it contains should result in more principled sentencing, while its codification of the purpose and principles of sentencing should promote a somewhat more uniform response to juvenile offending.

However, youth justice courts will continue to exercise considerable discretion with respect to the imposition of specific sanctions. Moreover, factors like the discretion permitted provincial correctional authorities with respect to diversion of cases from the youth justice courts to "extrajudicial measures" and many of the community-based sentencing options that they will make available, as well as the acceptance of variation in youth justice court sentences based on "regions," will likely mean that there will continue to be a great deal of variability across Canada in responses to youth offending. With regard to the critical issue of the use of custody, the relevant provisions in the $Y C J A$ must be considered in an international context. To date, no other country that has placed the principles of sentencing on a statutory footing has used such directive language to reduce the use of custody as a sanction. In all likelihood, then, the volume of admissions to custody at the youth justice court level will significantly decline under the new Act.

The sentencing provisions of the Act are not without their critics. Some commentators have criticized the $Y C J A$ for placing too much emphasis on proportionality and not enough 
on the seriousness of the offence. ${ }^{129}$ Others have argued that the Act moves youth justice in a direction opposite to the more rehabilitative approach that has been pursued in the province of Quebec, ${ }^{130}$ although, as we have discussed, the effect of the Reference decision of the Court of Appeal in that province may continue to give Quebec's youth justice courts significant discretion to "balance" rehabilitative and accountability concerns.

We concur with Anand ${ }^{131}$ that however carefully-crafted the statute may be or however diligently it is applied by the judiciary, the success of the new law will, in significant measure, depend upon the willingness of both levels of government to provide sufficient funding and resources to support the regime. Without adequate community-based sentencing alternatives that can both constrain and rehabilitate a youth, there is the real prospect that judges will be reluctant to substantially reduce the use of youth custody. ${ }^{132}$ As Turpel-Lafond J. notes, "[d]espite the image society might have of the judiciary, judges can only implement legislation when community and institutional resources have been provided."133

How rapidly and how radically will the new legislation change sentencing patterns? Early indications are that sentencing will change considerably, even without changes in community resources. Within the first few months of the new regime, a number of judgments have demonstrated the imposition of sanctions that would have been unlikely or impossible under the $Y O A$. Three cases are particularly illustrative.

In R. v. D.(K.), ${ }^{134}$ a 15 year old girl who had serious mental health problems and was in the care of the Department of Community Services was found guilty of uttering threats and assault for an incident that resulted from the use of physical restraints at the facility in which she resided. She had eight prior findings of guilt for similar offences under the YOA. With respect to the matter on deterrence, Lynch J. noted that "when I look at the Youth Criminal Justice Act, deterrence is not something that is given high or any profile." 135 The sentence imposed was simply a judicial reprimand. While noting that her behaviour was not appropriate, Justice Lynch was concerned about the inappropriate use of the youth justice court for youth in the care of the state. Reliance on the youth justice court to deal with

Jean Trépanier, "Loi sur le système de justice pénale pour les adolescents" (session de formation des judges de la cour du Québec, 14-17 Janvier 2003) (Montreal: École de Criminologie, Université de Montréal, 2003) at 65.

Marc Le Blanc, "Opinion soumise à la Cour diappel du Quebec dans le cadre du renvoi concernant le projet de loi C-7: loi sur le systeme de justice penale pour les adolescents" (Montreal: École de Criminologie, Université de Montréal, 2002) at 11, notes the low rate of youth custody in Quebec and adds that: "Les articles sur la détermination de la peine de la Loi sur le système de justice pénale pour les adolescents vont totalement à l'encontre de ce fondement qui fait consensus au Quebec". Le modèle quebecois de justice et de réadaption pour les adolescents, une approche faconnée par un quart de siècle d'experimentation et d'évaluation et ignorée par la Loi sur le système de justice pénale pour les adolescents. Anand, supra note 70 at $958,962-63$.

132 For example, some provinces, such as Saskatchewan and Ontario, have refused to implement the community-based intensive support and supervision order, while other provinces are making this option available. It is likely that those provinces which fail to make available community-based sentencing options will not experience the same degree of impact from the $Y C J A$ in terms of custody reduction as will those provinces that make these options available. 
discipline problems that constitute minor criminal offences committed by adolescents who are in the care of child welfare agencies has been a major concern. It was one of the causes of Canada's high rate of custody use under the YOA. This decision clearly signals a judicial response to that concern.

In $R v . M$. (H.A.), ${ }^{136}$ a young offender was convicted of aggravated assault. The victim had been kicked repeatedly and, as a result, lay in a coma for weeks, emerging with serious permanent brain damage, including almost total loss of speech. The offender was given credit for three months pre-trial custody and received a six month deferred custody and supervision order. Under the $Y O A$, a term of custody would have been inescapable for this type of case. While that case may well prove to be an anomaly, it suggests that the statutory exclusion for a DCSO contained in s. 42(5)(a) may not always succeed in preventing the imposition of a conditional term of custody for an offence that most people would be surprised to learn was not considered by the court to be a "serious, violent" offence. ${ }^{137}$

Finally, the lengthy and thoughtful judgment of Turpel-Lafond, J. in $M$.(B.) provides further illustration of the impact of the new sentencing provisions. The Aboriginal youth in that case was convicted of robbery and assault and, at the time of the offences, was serving an 18 month open custody sentence. The court rejected a joint submission for a two year secure custody sentence and instead initiated a process of conferencing and searching for community resources. The judge found "the engagement of the young person" in the conferencing process to be "most encouraging"; a supportive aunt and uncle were located as part of the sentencing process, and they offered to have the youth live with them. ${ }^{138}$ The court was impressed by the stability and support that these relatives would provide, emphasizing that they lived on a reserve far from the city were the youth had begun to engage in gangrelated criminal activities. The court imposed a sentence of 18 months' probation, with extensive rehabilitation-oriented terms. This offender, too, would clearly have been incarcerated under the previous youth justice regime. Once again, the objective of deterrence was explicitly discarded: the judgment notes that "the YCJA does not allow the Court to consider what would be a factor in adult sentencing — that is the principle of deterrence."139

137 The government has declared that, among other goals, the Youth Justice Renewal Initiative is designed to "increase public confidence in the youth justice system": Canada, Department of Justice, News Release, "Minister of Justice Reintroduces Youth Criminal Justice Act" (5 February 2001), but if a DCSO is used to address such crimes, the exact opposite result will occur. 